\title{
Przystosowanie konstrukcji nośnej lokomotywy serii EU07 do nowych parametrów eksploatacyjnych
}

\begin{abstract}
$W$ artykule zaprezentowano zmiany w konstrukcji nośnej lokomotywy typu 303Ea powstatej przez modernizacje lokomotywy typu 4E/303E serii EU07.

Zabudowa nowego wyposażenia oraz spetnienie podwyższonych parametrów eksploatacyjnych wymagaty zmodyfikowania ostoi i pudla lokomotywy. Przedstawione $w$ artykule zmiany $w$ konstrukcji wykonano $w$ oparciu o przeprowadzone symulacje, analizy wytrzymatościowe i dynamiczne pojazdu oraz wykonane próby i badania stanowiskowe podzespołów. Prawidłowość zastosowanych rozwiqzań weryfikowana jest $w$ trwajacych próbach eksploatacyjnych realizowanych przez PKP IC, ZNTK Oleśnica i IPS „,TABOR”. Lokomotywa kursuje z pociagiem "Fredro” na trasie Wrocław - Warszawa.

Projekt zostal zrealizowany wspólnie przez Instytut Pojazdów Szynowych „,TABOR” $i$ ZNTK Oleśnica S.A. w oparciu o dofinansowanie przyznane przez Ministra Nauki $i$ Szkolnictwa Wyższego decyzja nr 04490/C.ZR6-6/2009.
\end{abstract}

\section{Wprowadzenie}

Opracowana dokumentacja dotyczy największej z dotychczasowych modernizacji lokomotyw typu 4E/303E serii EU07. Obiektem przeznaczonym do wdrożenia projektu była lokomotywa typu 303E nr 495 przedstawiona na rys. 1. Lokomotywa została wyprodukowana przez Fabrykę Wagonów HCP w Poznaniu. W odniesieniu do produkowanych w latach 1965 - 1974 przez wrocławski „Pafawag” lokomotyw typu 4E, poznańskie pojazdy nieznacznie zmodyfikowano. Odróżniały się one przystosowaniem do zabudowy sprzęgu samoczynnego oraz ryflowanym poszyciem ścian bocznych. Skutkowało to wzrostem masy własnej i długości lokomotywy.

Realizując projekt modernizacji, wymieniono $\mathrm{w}$ pudle pojazdu wszystkie urządzenia, oraz zastosowano nowoczesną aparaturę. Zabudowano nowoczesny system zasilania sprężonego powietrza $\mathrm{z}$ tablicą pneumatyczną. Układy biegowe z nowymi asynchronicznymi silnikami trakcyjnymi o większej mocy przystosowano do zwiększonej prędkości $160 \mathrm{~km} / \mathrm{h}$. Lokomotywę wyposażono w mikroprocesorowy system sterowania i diagnostyki [1].

Do zabudowy nowego wyposażenia oraz spełnienia nowych wymagań eksploatacyjnych konieczna była adaptacja ostoi i pudła lokomotywy. Wszystkie zmiany $\mathrm{w}$ konstrukcji lokomotywy wykonano w oparciu o przeprowadzone symulacje, analizy wytrzymałościowe i dynamiczne pojazdu. Po przeprowadzeniu prób i badań, lokomotywa uzyskała terminowe świadectwo dopuszczenia do eksploatacji nr T/2011/0905 ważne do 31-03-2013, umożliwiające prowadzenie prób eksploatacyjnych podczas których weryfikowana jest prawidłowość przyjętych rozwiązań.
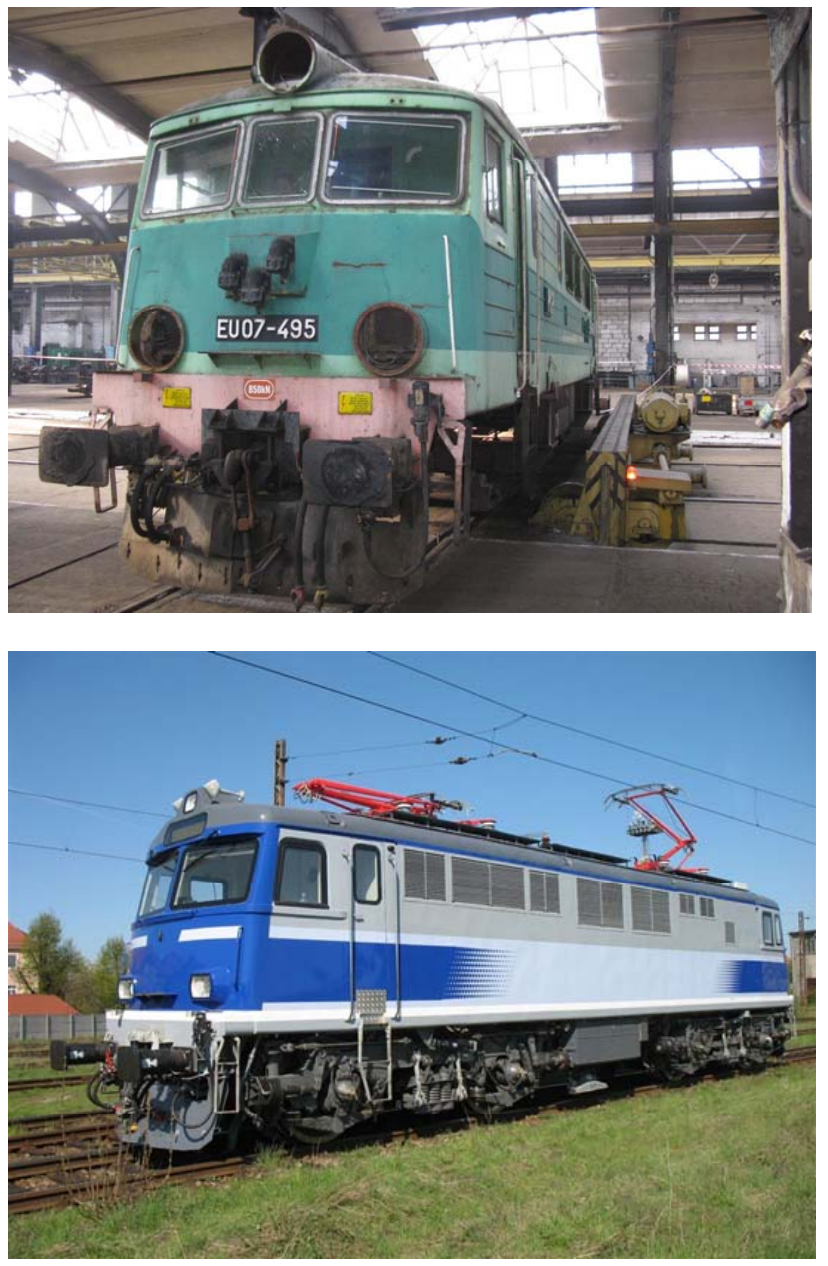

Rys. 1 Lokomotywa przed i po modernizacji 


\section{Opis modernizacji konstrukcji nośnej}

Zaprojektowany układ wyposażenia zmodernizowanej lokomotywy przedstawia rys. 2 [2]. Przystępując do rozmieszczenia nowego wyposażenia w lokomotywie uwzględniono przede wszystkim wymagania dotyczące wentylacji urządzeń oraz ich masę. Z tego powodu jako pierwsze ustawiono kolumny rezystorów hamowania. $Z$ uwagi na zapotrzebowanie dużej ilości powietrza spod pojazdu najlepszą lokalizacją zapewniającą swobodny jego pobór było miejsce nad dotychczasową zabudową boczników. Przepływ powietrza odbywa się przez pionową rurę wspawaną w ostoję. Rura o średnicy $640 \mathrm{~mm}$ łączy płytę górną z poszyciem dolnym i zapewnia prawidłowe przeniesienie obciążeń przez konstrukcję ostoi. Wyrzut gorącego powietrza następuje przez połączony elastycznie $\mathrm{z}$ kolumną rezystora wylot zamontowany w dachu odejmowalnym. W środkowej części przedziału maszynowego obok rezystorów zabudowano tablicę pneumatyczną, sprężarkę pomocniczą i szafę niskiego napięcia.

Lewą stronę środkowej części zabudowano szafą rozdzielnicy wysokiego napięcia. Szafy zamocowane zostały łącznikami śrubowymi do ceowników przyspawanych do podłogi oraz do wsporników przyspawanych na górnej podłużnicy ściany bocznej.

Urządzenia w środkowej części przedziału maszynowego chłodzone są powietrzem w obiegu wewnętrznym przedziału. W tym celu, w środkowej części ścian bocznych pozostawiono poprzedni układ czterech żaluzji zapewniających wymaganą wentylację przedziału. W skrajnych częściach przedziału maszynowego nad wózkami po przekątnej rozmieszczono szafy falowników trakcyjnych. Falowniki są chłodzone powietrzem przepływającym $\mathrm{z}$ góry do dołu. Powietrze zasysane jest $\mathrm{z}$ zewnatrz lokomotywy poprzez prostokątny pas żaluzji zabudowany w górnej części ściany bocznej i wydmuchiwane pod szafy falowników. Pod nimi wykonano układ kanałów pionowych i poziomych przebiegających przez ostoję, którymi powietrze wydmuchiwane jest w przestrzeń nad wózkiem. Ostoja lokomotywy zbudowana jest z profili walcowanych i giętych cienkich profili.
Od góry i dołu pokryta jest blachami stanowiąc zamkniętą konstrukcję skrzynkową. Przy takiej budowie, część kanałów wylotowych wykonano z przestrzeni ostoi odpowiednio wzmacniając je szeregiem pionowych żeber. Widok otworów wentylacyjnych od spodu ostoi przedstawiono na rys. 3 .

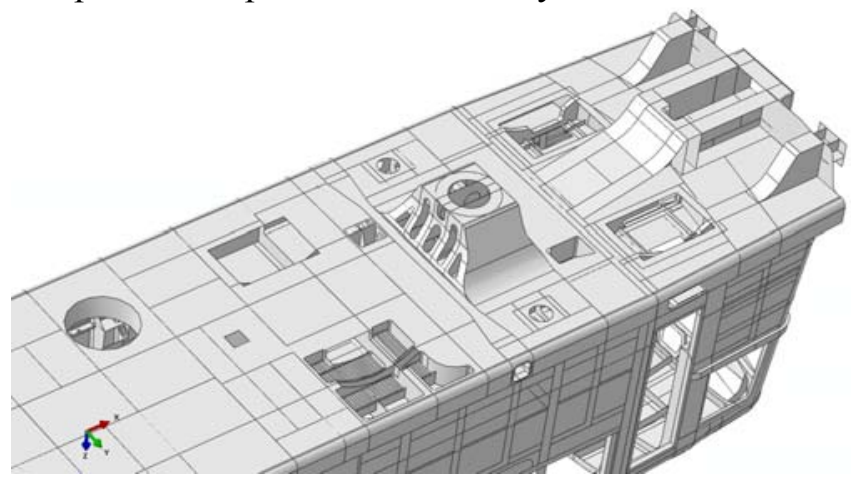

Rys. 3 Układ otworów wentylacyjnych w ostoi

Ostoję wyposażono również $\mathrm{w}$ nowe wsporniki zmodyfikowanego układu połączenia pudła $\mathrm{z}$ wózkami jezdnymi. Na prawej ścianie od strony kabiny 1 zabudowano żaluzje kanału do układu agregatów sprężarkowych z układem uzdatniania powietrza. Sposób zabudowy umożliwia odsunięcie agregatów od żaluzji co stosuje się w okresie zimowym podczas dużych mrozów, tak by agregaty nie zasysały powietrza bezpośrednio z zewnątrz lokomotywy. Po przekątnej od strony kabiny 2 zabudowano żaluzje wylotowe powietrza chłodzącego przetwornicę statyczną.

Z uwagi na zmianę ilości, układu i wymiarów żaluzji wymieniono blachę poszycia pudła lokomotywy. Dotychczasowe ryflowane poszycie ścian bocznych zastąpiono gładką blachą o zwiększonej odporności na korozję.

$\mathrm{Na}$ ścianach bocznych zlikwidowano zewnętrzne drzwi do przedziału maszynowego. Umożliwiło to zabudowę klimatyzatorów kabin przy ścianie, których $\mathrm{z}$ uwagi na ograniczoną przestrzeń nie można było zabudować pod pulpitem, tak jak w dotychczas modernizowanych lokomotywach.

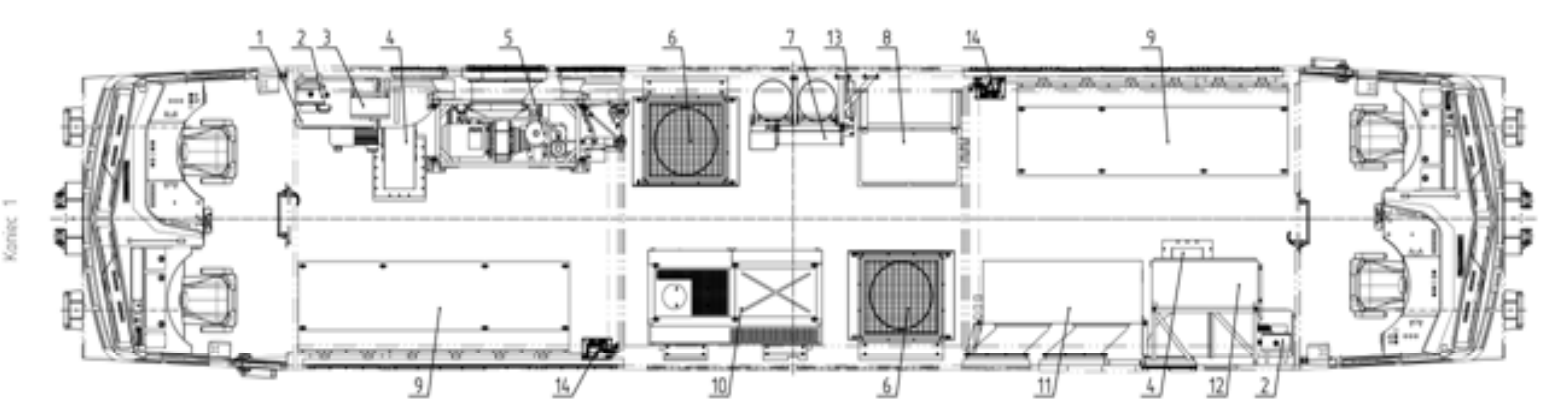

Rys. 2 Układ wyposażenia lokomotywy:. 1- klimatyzator 2- sterownik klimatyzatora 3- monitoring GSM, 4- wentylator silników trakcyjnych, 5- sprężarki z układem uzdatniania powietrza, 6- rezystor hamowania RH, 7- tablica pneumatyczna, 8szafa NN, 9- falownik 10- szafa RWN, 11- przetwornica, 12- szafa elektroniki, 13- stanowisko ładowania lamp końcowych, 14- zbiornik układu smarowania obrzeży 
Pod klimatyzatorami w ostoi wykonano kanały wylotowe zużytego powietrza, obok pozostawiono bez zmian dotychczasowe kanały wentylacyjne silników trakcyjnych.

Środkiem, wzdłuż osi lokomotywy na podłodze zabudowano podest przejściowy pomiędzy kabinami przykrywający kanał kablowy WN i kanał pneumatyczny.

Zabudowa zamodelowanego układu urządzeń na dotychczasowym obiekcie wymagała likwidacji dwóch przegród przedziału stanowiących jednocześnie podporę dachów przedstawioną na rys. 4. Ich funkcję w konstrukcji przejęły nowo zaprojektowane poprzecznice górne. Zmieniono również ich usytuowanie wzdłużne w celu umożliwienia bezkolizyjnego pionowego montażu wyposażenia. W wyniku tego zmieniono również długości dachów odejmowalnych. Na rys. 5 przedstawiono pudło lokomotywy ze zdemontowanymi blachami poszycia i zamontowanymi nowymi poprzecznicami.

Czoło lokomotywy przystosowano do zabudowy nowych reflektorów świateł głównych i sygnałowych, wklejanych dwóch szyb czołowych w miejsce dotychczasowych trzech i tablicy kierunkowej. W szkielecie ścian bocznych kabiny przygotowano miejsce na zabudowę mechanizmu opuszczania nowych okien bocznych. W wyniku likwidacji dwóch słupków na czole należało wzmocnić pasy pod i nad oknami czołowymi. Przebudowe pasa nadokiennego i dachu kabiny przedstawiono na rys. 6 . a na rys. 7 przedstawiono zmodernizowane czoło lokomotywy z wklejoną jedną szyba, przygotowaną do testu odporności na przebicie szyby czołowej. Właściwy stan szyby po uderzeniu pociskiem o masie $1 \mathrm{~kg} \mathrm{z}$ prędkością $320 \mathrm{~km} / \mathrm{h}$ przedstawiono na rys. 8.

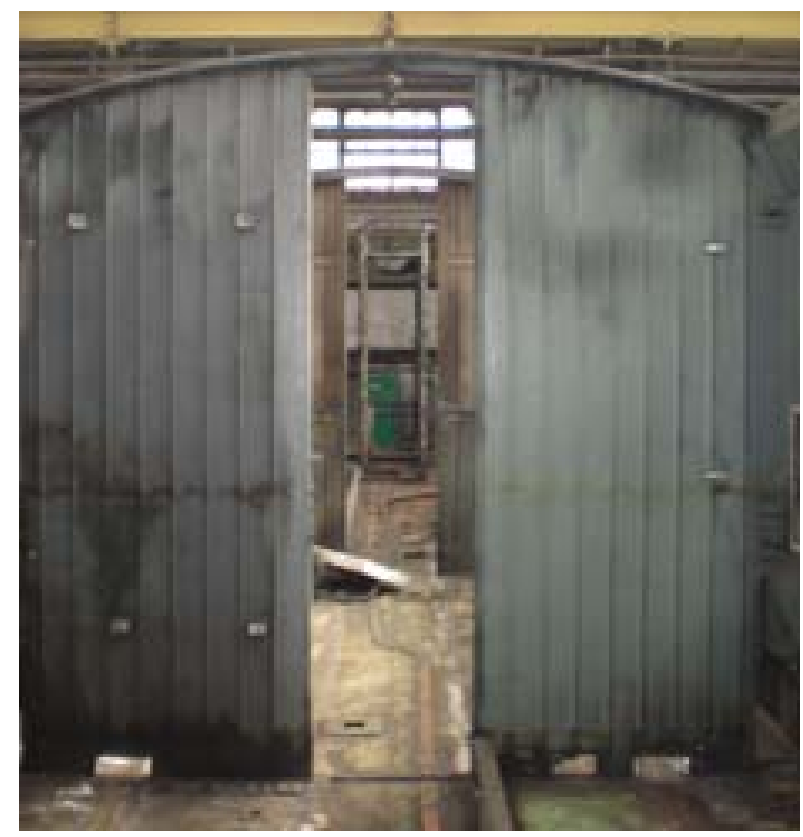

Rys. 4 Ściany przedziału

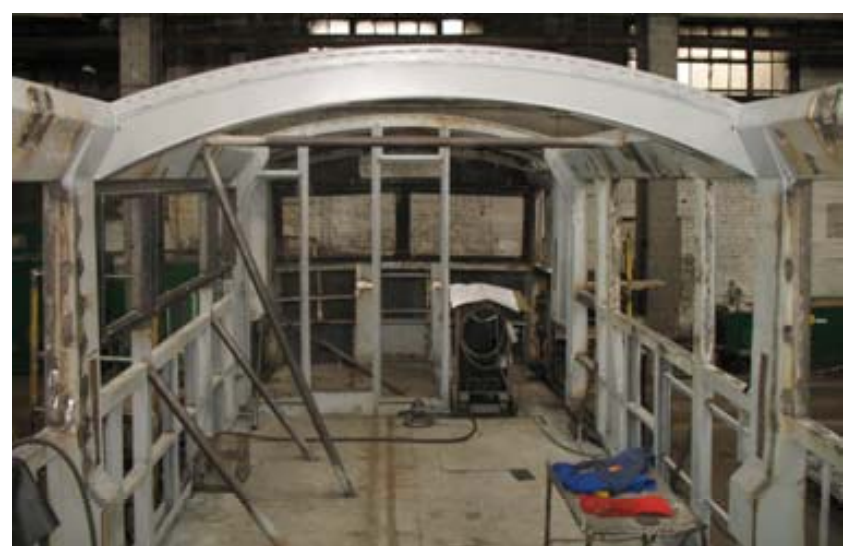

Rys. 5 Poprzecznica górna

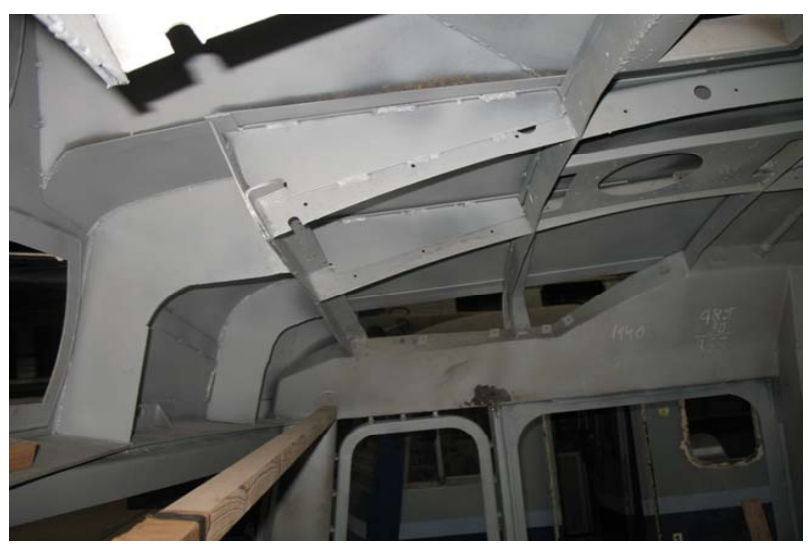

Rys. 6 Przebudowa dachu kabiny

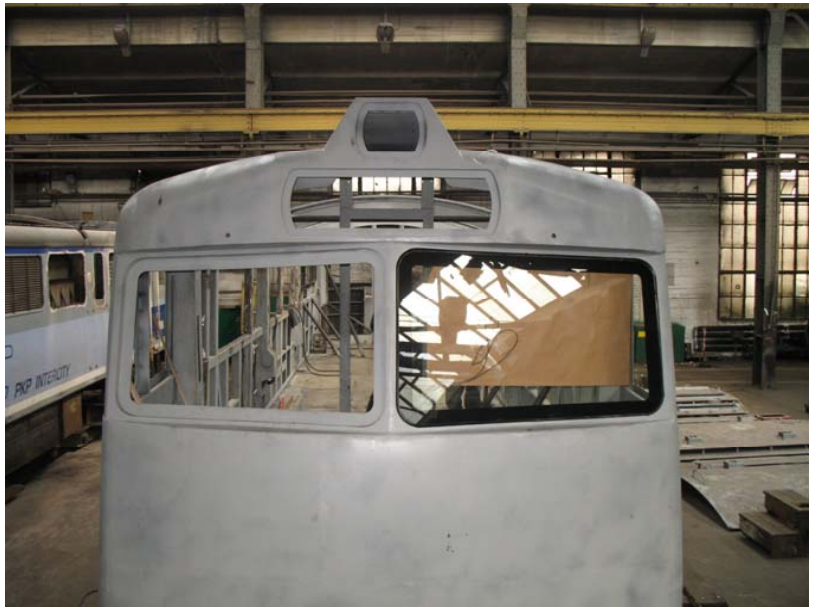

Rys. 7 Czoło lokomotywy

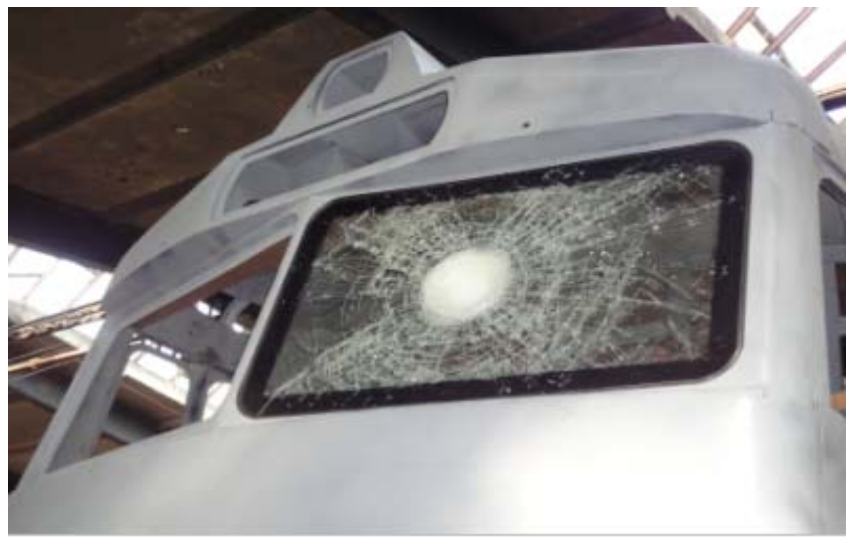

Rys. 8 Szyba czołowa po teście odporności. 

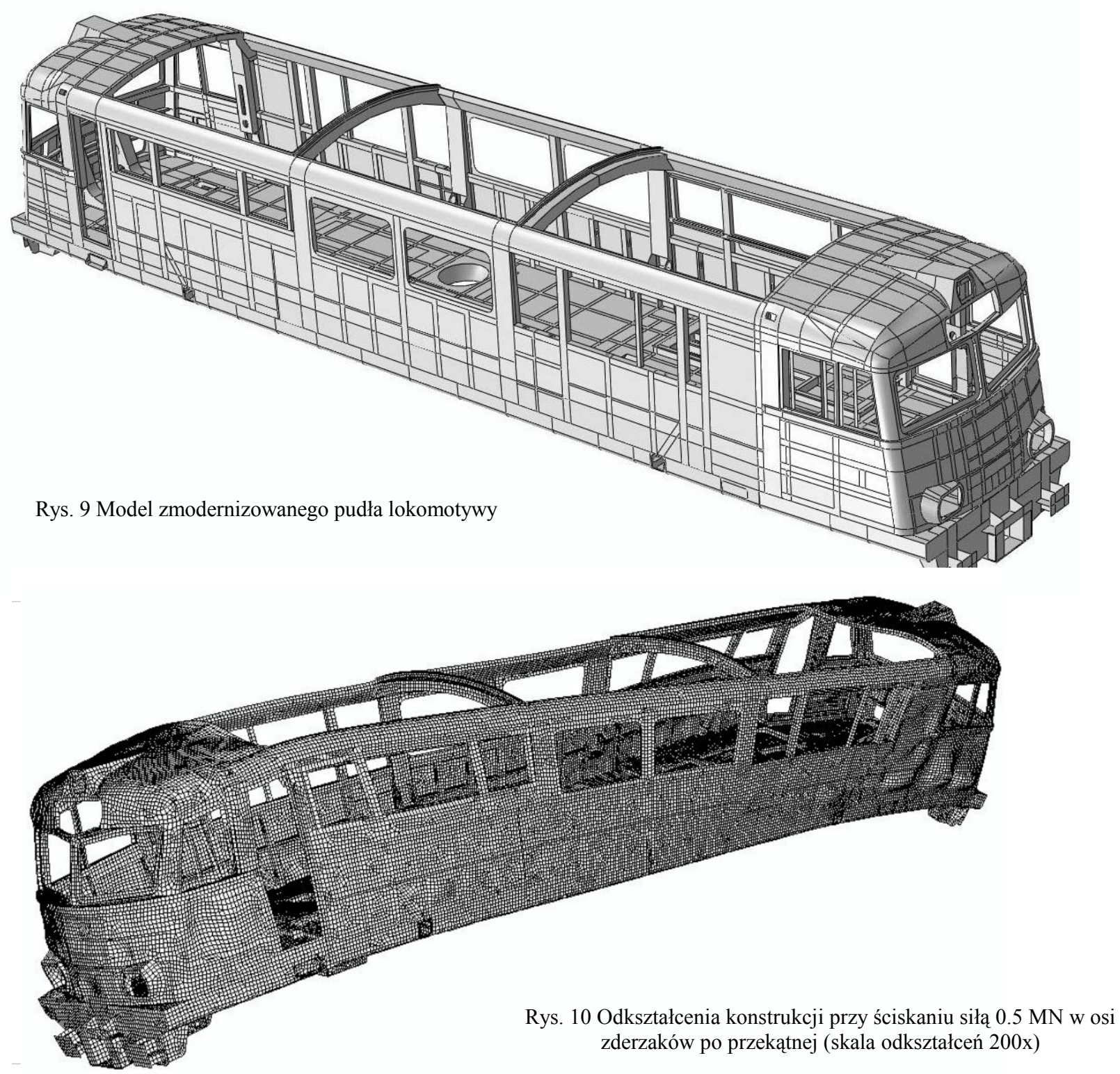

Wszystkie przedstawione zmiany wprowadzone w konstrukcji pudła zostały wcześniej zamodelowane przy wykorzystaniu oprogramowania 3D SolidWorks. Powstały przestrzenny model pokazany na rys. 9 poddano analizie wytrzymałości wykonanej metodą elementów skończonych programem Abaqus 6.2. Wyznaczone rozkłady naprężeń umożliwiły wybór optymalnych rozwiązań modernizacji. Oprócz rozkładu naprężeń dla każdego przypadku obciążenia wyznaczono postać odkształconej konstrukcji, co pozwoliło na analizę wpływu wprowadzanych zmian i uzyskanie minimalnych deformacji pudła. Przykładowe odkształcenia obliczeniowego modelu podzielonego na elementy skończone przedstawiono na rys. 10 .

\section{Podsumowanie}

Wykorzystanie nowoczesnych narzędzi wspomagających projektowanie konstrukcji umożliwiło optymalną adaptację starej konstrukcji nośnej lokomotywy do nowych warunków eksploatacyjnych. Przeprowadzona analiza wytrzymałości potwierdziła, że zmodernizowana konstrukcja nośna lokomotywy 303Ea spełnia aktualnie obowiązujące wymagania konstrukcyjno - wytrzymałościowe dotyczące pudeł kolejowych pojazdów szynowych według normy PNEN 12663-1.

\section{Lit er a tura}

[1] Czerwiński J., Lastowski M., Krajewski S., Szymczak J. ;Modernizacja lokomotywy serii EU07.Technika Transportu Szynowego 3/2011

[2] IPS „TABOR”; Dokumentacja konstrukcyjna i techniczna lokomotywy 303Ea. 